\title{
PENINGKATAN HASIL BELAJAR SISWA SEKOLAH DASAR DENGAN PENERAPAN MODEL STAD (STUDENT TEAM ACHIEVEMENT DIVISION) BERBANTUAN MEDIA PUZZLE
}

\author{
Hestining Ardiyanti, Erik Aditya Ismaya, dan Deka Setiawan
}

Universitas Muria Kudus

Email: hesti.ardiyanti95@gmail.com

\section{Info Artikel}

Sejarah Artikel:

Diserahkan 26 Agustus 2020

Direvisi 10 Mei 2021

Disetujui 18 Mei 2021

Keywords:

STAD Model

Puzzle

Learning Outcome

\section{Abstract}

This study aims to describe the application of the STAD (Student Teams Achievement Division) learning model assisted by the puzzle media and to find an increase in student learning outcomes on the theme of 6 Heat and Its Transfer in My Country, grade V SD 7 Cendono.

Classroom action research was carried out in class V SD 7 Cendono with 22 students as the research subject. This research lasted for two cycles, each cycle consisting of four stages, namely planning, implementing, observing, and reflecting. The independent variable is the STAD model. While the dependent variable is student learning outcomes. The research instruments were tests and documentation. The data analysis technique used is qualitative and quantitative data analysis techniques.

The results showed that the application of the STAD learning model assisted by puzzle media could improve student learning outcomes. Student learning outcomes have increased from cycle I to cycle II, namely from the percentage of student completeness of $43 \%$ to $86 \%$.

\begin{abstract}
Abstrak
Penelitian ini bertujuan untuk mendiskripsikan penerapan model pembelajaran STAD (Student Teams Achievement Division) berbantu media Puzzle dan menemukan peningkatan hasil belajar siswa pada tema 6 Panas dan Perpindahannya di Negeriku kelas V SD 7 Cendono.

Penelitian tindakan kelas dilaksanakan di kelas V SD 7 Cendono dengan subjek penelitian adalah 22 siswa. Penelitian ini berlangsung selama dua siklus, setiap siklus terdiri dari empat tahap yaitu perencanaan, pelaksanaan, pengamatan, dan refleksi. Variabel bebas adalah model STAD. Sedangkan variabel terikat adalah hasil belajar siswa. Instrumen penelitian ini adalah tes dan dokumentasi. Teknik analisis data yang digunakan adalah teknik analisis data kualitatif dan kuantitatif.

Hasil penelitian menunjukkan dengan penerapan model pembelajaran STAD berbantuan media Puzzle dapat meningkatkan hasil belajar siswa. Hasil belajar siswa mengalami peningkatan dari siklus I ke siklus II yaitu dari presentase ketuntasan siswa sebesar $43 \%$ menjadi $86 \%$.
\end{abstract}




\section{PENDAHULUAN}

Pendidikan merupakan salah satu usaha untuk mewujudkan terciptanya proses pembelajaran yang dapat mengembangkan potensi seseorang. Pendidikan diberikan untuk mengembangkan kemampuan dan kekuatan individu. pendidikan diharapkan mampu mendewasakan seseorang melalui proses pembelajaran. Kemajuan suatu bangsa sangat ditentukan oleh kualitas sumber daya manusia, sedangkan kualitas sumber daya manusia tergantung pada kualitas pendidikanya.

Hasil belajar sebagai objek penilaian pada hakikatnya menilai penguasaan siswa setelah menerima dan menyelesaikan pengalaman belajarnya. Sudjana (2011) menyatakan bahwa hasil belajar adalah kemampuan-kemampuan yang dimiliki siswa setelah ia menerima pengalaman belajarnya.

Observasi yang dilakukan di kelas V SD 7 Cendono ditemukan suatu permasalahan bahwa ketika guru melakukan proses pembelajaran guru jarang menggunakan media sebagai penunjang pembelajaran. Guru masih menggunakan metode ceramah dan guru belum menerapkan modelmodel pembelajaran sesuai dengan kebutuhan siswa. Hal tersebut menyebabkan siswa merasa bosan sehingga kurang antusias dalam mengikuti pembelajaran. Siswa juga sering berbicara sendiri dengan teman sebangkunya. Selain itu, saat guru selesai menjelaskan materi guru memberikan kesempatan untuk bertanya namun masih banyak siswa yang hanya diam dan tidak bertanya meskipun masih belum memahami materi yang disampaikan oleh guru.

Pada saat observasi peneliti juga menemukan beberapa kelemahan dalam keterampilan menulis yaitu 1) siswa belum mampu membuat ringkasan dikarenakan siswa merasa takut jika tulisan yang dibuatnya salah, dan 2) siswa masih kesulitan dalam pemilihan kata yang tepat dalam menyusun kalimat yang benar. Tidak hanya dalam keterampilan menulis, siswa juga memiliki kelemahan dalam berinteraksi dengan siswa yang lainnya sehingga waktu guru mengadakan diskusi kelompok siswa masih individualis dalam mengerjakan tugasnya. Siswa tidak berani untuk bertanya kepada guru apabila ada hal yang belum dipahami. Hal tersebut akan berpengaruh terhadap hasil belajar siswa. Hasil nilai ulangan tengah semester (UTS) kelas V SD 7 Cendono pada muatan IPS dan Bahasa Indonesia diketahui masih dibawah kriteria ketuntasan maksimal (KKM) sebesar 70. Pada muatan IPS terdapat 39\% (10 dari 23 siswa) yang sudah mengalami ketuntasan belajar sedangkan 61\% (13 dari 23 siswa) yang belum mengalami ketuntasan belajar dan pada muatan Bahasa Indoensia terdapat 43\% (11 dari 23 siswa) yang sudah mengalami ketuntasan belajar sedangakan 57\% (12 dari 23 siswa) yang belum mengalami ketuntasan belajar.

Penerapan model pembelajaran dapat membantu guru dalam menyampaikan pesan pembelajaran. Salah satu model pembelajaran yang dapat meningktakan aktivitas siswa dalam pembelajaran yaitu model STAD (Student Teams Achicement Divisions). Model Pembelajaran STAD (Student Teams Achicement Divisions) merupakan salah satu strategi pembelajaran kooperatif, yaitu kegitan belajar mengajar dengan cara menggelompokan siswa ke dalam kelompokkelompok kecil. Hal ini ditunjukkan agar saling bekerjasama, saling membantu hingga mencapai hasil belajar yang maksimal dari sebuah pembelajaran. Memilih model STAD (Student Teams Achicement Divisions) bertujuan untuk memotivasi para siswa, mendorong dan membantu satu sama lain, dan untuk menguasai keterampilan-keterampilan yang disajikan oleh guru. Model STAD (Student Teams Achicement Divisions) selain mempunyai tujuan untuk mengaktifkan siswa serta memotivasi siswa lebih bersemangat belajar (Dewi dkk, 2019).

Keunggulan model menunjukkan bahwa model tersebut mempunyai kualitas untuk mengatasi permasalahan yang ada. Keunggulan model Model STAD (Student Teams Achicement Divisions) yaitu, siswa aktif membantu dan memotivasi semangat untuk berhasil bersama (Kusumawati dan Mawardi, 2016). Interaksi antar siswa seiring dengan peningkatan kemampuan mereka dalam berpendapat, dapat membantu siswa menelaah materi dan siswa yang kurang aktif ikut berpatisipasi. Penerapan model STAD (Student Teams Achicement Divisions) ini sangatlah cocok digunakan untuk mengatasi masalah kurangnya konsentrasi siswa dan rendahnya hasil belajar siswa di SD 7 Cendono.

Penggunaan model pembelajaran dapat efektif apabila dibantu dengan penggunaan media pembelajaran. Penggunaan media pembelajaran dapat membantu guru dalam menyampaikan pedan pembelajaran (Ningsih dkk, 2020). Salah satu media pembelajaran yang menarik dan dapat mengaktifkan siswa adalah media puzzle. Penggunaan media Puzzle dirasakan sangat tepat untuk membantu siswa dalam memahami materi yang disampaikan oleh guru. Selain itu siswa yang melihat gambar Puzzle dapat menarik isi kesimpulan dari gambar, kemudian dapat menguraikan dengan tulisan. Salah satu media yang digunakan guru dalam upaya meningkatkan hasi belajar adalah menggunkan media puzzle. Sebagaimna halnya media lain media puzzle 
berfungsi untuk menyalurkan pesan dari sumber ke penerima pesan. Media Puzzle mampu memberikan detail dalam bentuk gambar apa adanya, sehingga siswa akan mampu untuk mengingatnya (Khomsoh, 2013). Media ini dianggap paling mudah dipahami siswa karena dapat menempatkan informasi ke dalam otak dan mengambil informasi itu ketika dibutuhkan. Sehingga pembelajaran yang dilakukan akan menjadi lebih hidup, variatif. Dalam penelitian ini, peneliti mengambil tema VI Panas dan Perpindahannya pada subtema 2, subtema 3 dan dengan muatan IPS dan Bahasa Indonesia. Adapun materi yang akan dibahas muatan IPS difokuskan Bentuk-bentuk interaksi manusia dengan lingkungan dan pengaruhnya terhadap pembangunan sosial, budaya, dan ekonomi masyarakat Indonesia sedangkan muatan Bahasa Indonesia difokuskan pada Teks pejelasan (ekspalanasi) dari media cetak atau elektronik dan Teks nonfiksi.

Tujuan dalam penelitian ini adalah untuk mendiskripsikan penerapan model pembelajaran STAD (Student Teams Achievement Division) berbantu media Puzzle dan mengkaji peningkatan hasil belajar siswa pada tema 6 Panas dan Perpindahannya di Negeriku kelas V SD 7 Cendono.

\section{METODE PENELITIAN}

Subjek penelitian ini yakni peneliti sebagai guru dan siswa kelas V SD 7 Cendono Kudus yang berjumlah 23 siswa yang terdiri dari 13 siswa laki-laki, dan 10 siswa perempuan. Pelaksanaan tindakan ini dengan menerapkan model pembelajaran Student Teams Achievement Devision pada Tema VI Panas dan Perpindahannya untuk meningkatkan hasil belajar kelas V semester II SD 7 Cendono. Pelaksanaan penelitian berlangsung selama 2 siklus dengan mengikuti empat tahapan penelitian tindakan kelas, yaitu perencanaan, pelaksanaan, pengamatan, refleksi (Sugiyono, 2016).

Teknik pengumpulan data dalam penelitian ini adalah dokumentasi, dan tes. Dokumentasi bertujuan untuk mengumpulkan data selama penelitian dilaksanakan dalam bentuk foto. Sedangkan tes dilaksanakan dengan tujuan mengukur kemampuan prestasi belajar siswa dalam tiap akhir siklus.

Analisis data yang digunakan adalah analisis data kuantitatif dan kualitatif. Analisis data kuantitatif diukur dengan menentukan ketuntasan individu dan kemudian dilakukan perhitungan ketuntasan klasikal. Sedangkan analisis data kualitatif dilakukan dengan analisis deskriptif yaitu reduksi data, mendeskripsikan data dan membuat kesimpulan. Jika ketuntasan klasikal mencapai $75 \%$ maka indikator keberhasilan telah tercapai, jika kurang dari $75 \%$ maka indicator keberhasilan belum tercapai. Ketuntasan individu dapat dilihat dengan cara membandingkan nilai siswa dengan criteria ketuntasan minimal yaitu 70 .

\section{HASIL DAN PEMBAHASAN 1. Prasiklus}

Penelitian tindakan kelas ini diawali dengan wawancara dan observasi yang dilaksanakan di SD 7 Cendono Dawe Kudus. Sebelum melakukan penelitian, peneliti melakukan wawancara dan observasi terhadap guru kelas dan siswa kelas V. Dari hasil wawancara dan observasi yang dilakukan peneliti menunjukkan bahwa aktivitas siswa masih rendah, hal tersebut disebabkan cara mengajar guru yang masih konvensional terutama pada pembelajaran tematik pada muatan IPS dan Bahasa Indonesia.

Peneliti melakukan tahap prasiklus dengan melakukan studi dokumentasi dan nilai pretes siswa pada muatan IPS dan Bahasa Indonesia pada kelas V SD 7 Cendono sebagai nilai prasiklus. Berdasarkan penelitian yang dilakukan nilai prasiklus tema 6 panas dan perpindahnnya yang digunakan peneliti memperoleh total skor seluruh siswa sebesar 1680 dengan jumlah Siswa tuntas 8 siswa dengan presentase $35 \%$ dan 15 siswa tidak tuntas dengan presentase $73 \%$.

\section{Siklus I}

Penelitian siklus I dilaksanakan selama 2 kali pertemuan. Selama penelitian siklus I dilaksanakan di ruang kelas V SD 7 Cendono . Pelaksanaan setiap pertemuan terdiri dari 4 jam pelajaran (4 x 35 menit). Pada tahap perencanaan dilakukan persiapan perangkat pembelajaran dengan model STAD berbantuan media puzzle. Selanjutnya pada tahap pelaksanaannya dilakukan pembelajaran di kelas $\mathrm{V}$ dengan menerapkan model STAD berbantuan media puzzle. Selama proses pembelajaran dilakukan pengamatan baik pada siswa maupun guru menggunakan lembar observasi. Tahap terakhir pada siklus I yaitu tahap refleksi untuk menemukan kekurangan sebagai bahan perbaikan pada siklus II.

Pada akhir siklus I dilakukan tes evaluasi akhir. Rekapitulasi hasil tes evaluasi pada siklus I disajikan pada Tabel 1 berikut. 
Tabel 1. Rekapitulasi hasil tes evaluasi siklus I

\begin{tabular}{lc}
\hline \multicolumn{1}{c}{ Komponen } & Nilai \\
\hline Skor Maksimal & 87,5 \\
Skor Minimal & 50 \\
Total Skor & 1578,06 \\
Rata-rata & 71,73 \\
Siswa tuntas & 10 \\
Siswa tidak tuntas & 13 \\
Persentase Ketuntasan & $43,47 \%$ \\
\hline
\end{tabular}

Berdasarkan hasil evaluasi pada siklus I diketahui bahwa persentase ketuntasan klasikal belum memenuhi indicator keberhasilan, maka selanjutnya dilakukan tindakan lanjut yaitu pada siklus II.

\section{Siklus II}

Penelitian siklus II dilaksanakan 2 kali pertemuan. Selama penelitian siklus II dilaksanakan di ruang kelas V SD 7 Cendono . Pelaksanaan setiap pertemuan terdiri dari 4 jam pelajaran (4 x 35 menit). Pada penelitian tindakan kelas siklus II meliputi perencanaan, pelaksanaan, observasi, dan refleksi.

Pada akhir siklus II dilakukan tes evaluasi akhir. Rekapitulasi hasil tes evaluasi pada siklus II disajikan pada Tabel 2 berikut.

Tabel 2. Rekapitulasi hasil tes evaluasi siklus II

\begin{tabular}{lc}
\hline \multicolumn{1}{c}{ Komponen } & Nilai \\
\hline Skor Maksimal & 97 \\
Skor Minimal & 68 \\
Total Skor & 1842 \\
Rata-rata & 80,38 \\
Siswa tuntas & 20 \\
Siswa tidak tuntas & 3 \\
Persentase Ketuntasan & $86,95 \%$ \\
\hline
\end{tabular}

Berdasarkan Tabel 2 tersebut dapat dijelaskan bahwa tes evaluasi siklus II ketuntasan klasikal yaitu 20 siswa yang dinyatakan tuntas sesuai dengan KKM dengan persentase $87 \%$ dan terdapat 3 siswa yang dinyatakan belum tuntas sesuai dengan KKM dengan Persentase $13 \%$.

Berdasarkan hasil pada prasiklus, siklus I dan siklus II diketahui bahwa terdapat peningkatan rekapitulasi hasil belajar siswa. Peningkatan hasil belajar siswa dikarenakan penggunaan model pembelajaran STAD berbantuan media puzzle. Dewi (2017) dalam penelitiannya menemukan bahwa penerapan model STAD dapat meningkatkan hasil belajar siswa karena siswa dapat melakukan kegiatan diskusi dalam tim (kelompok). Penggunaan model STAD dapat memotivasi siswa untuk belajar secara kelompok, saling mendorong dan membantu sesame anggota kelompok dalam memahami atau menyelesaikan tugas yang diberikan oleh guru. Selain dapat meningkatkan hasil belajar siswa, model STAD juga dapat mempererat hubungan siswa dan dapat memberikan dampak positif yaitu kekompakkan dan kerjasama yang baik dalam kelompok. Hal tersebut senada dengan pendapat Febriyani dan Hardiono (2018) bahwa penerapan model STAD dapat meningkatkan aktivitas siswa terutama aktivitas siswa dalam berdiskusi di dalam kelompok.

Peningkatan hasil belajar siswa selain dikarenakan penerapan model pembelajaran STAD juga dikarenakan penggunaan media Puzzle. Penggunaan media pembelajaran sudah seperti hal penting dalm sebuah pembelajaran (Amalia dkk, 2020). Media puzzle membantu siswa dalam berpikir secraa kreatif untuk menemukan hal tertentu. Penggunaan media puzzle juga menarik bagi siswa usia sekolah dasar. Menurut Rakhma, dkk (2016) penggunaan media puzzle pada materi IPA membuat siswa sekolah dasar lebih tertarik dalam kegiatan pebelajaran. Hal senada disampaikan oleh Widyatmoko (2019) bahwa media game puzzle yang dikembangkan dengan memasukkan unsur budaya dapat menambah daya Tarik tersendiri bagi siswa. Siswa merasa tidak bosan dalam kegiatan pembelajaran karena dapat belajar sambal bermain menggunakan media puzzle.

\section{SIMPULAN}

Berdasarkan hasil yang diperoleh maka dapat disimpulkan bahwa penerapan model pembelajaran STAD berbantuan media Puzzle dapat meningkatkan hasil belajar siswa. Hasil belajar siswa mengalami peningkatan dari siklus I ke siklus II yaitu dari presentase ketuntasan siswa sebesar $43 \%$ menjadi $86 \%$.

\section{DAFTAR PUSTAKA}

Amalia, S. R., Fakhriyah, F., \& Ardianti, S. D. (2020). Peningkatan Kemampuan Berpikir Kritis Siswa Melalui Model Problem Based Learning Berbantuan Media Kotak Kehidupan Pada Tema 6 Cita-Citaku. WASIS: Jurnal Ilmiah Pendidikan, 1(1), 7-13.

Dewi, A. S., Isnani, I., \& Ahmadi, A. (2019). Keefektifan Model Pembelajaran STAD Berbantuan Media Pembelajaran Terhadap Sikap dan Kemampuan Pemecahan Masalah Matematika. JIPMat, 4(1). 
Dewi, Nurpala. 2017. Penerapan Pembelajaran Model Student Teams Achievement Division (STAD) Untuk Meningkatkan Pemahaman Siswa Pada Mata Pelajaran PKn Tentang Sistem Pemerintahan Pusat Di Kelas IV SDN Kedungmaya Kecamatan Cibogo Kabupaten Subang. BIORMATIKA Jurnal Ilmiah FKIP Universitas Subang, 3 (2), 1-11.

Febriyani dan Hardjono. 2018. Penerapan Model STAD Berbasis Scientific untuk Meningkatkan Aktivitas dan Hasil Belajar Tematik. Jurnal Riset Teknologi dan Inovasi Pendidikan, 2 (1), 66-78

Khomsoh, R. (2013). Penggunaan Media Puzzle Untuk Meningkatkan Hasil Belajar Siswa Dalam Pembelajaran Ilmu Pengetahuan Sosial di Sekolah Dasar. Jurnal Penelitian Pendidikan Guru Sekolah Dasar, 1(2), 111.

Kusumawati, H., \& Mawardi, M. (2016). Perbedaan Penerapan Model Pembelajaran Kooperatif Tipe NHT dan STAD Ditinjau dari Hasil Belajar Siswa. Scholaria: Jurnal Pendidikan dan Kebudayaan, 6(3), 251-263.

Ningsih, M., Sumarwiyah, S., \& Setiawan, D. (2020). Peningkatan Hasil Belajar Siswa Sekolah Dasar Melalui Model Student Facilitator And Explaining Berbantuan Media Rotar. WASIS: Jurnal Ilmiah Pendidikan, 1(2), 74-79.

Rakhma, I. S., Widyaningsih, U., \& Mawartiningsih, L. (2016). Pengembangan Magic Crossword Puzzle Sebagai Media Pembelajaran IPA Untuk Siswa Kelas V Sekolah Dasar. Refleksi Edukatika: Jurnal Ilmiah Kependidikan, 7(1), 69-77.

Sudjana, Nana. 2011. Penilaian Hasil Belajar Mengajar. Bandung: Remaja Rosdakarya.

Sugiyono. 2016. Metode Penelitian Pendidikan Pendekatan Kuantitatif, Kualitatif, dan R\&D. Bandung: CV.ALFABETA.
Widyatmoko, H. (2019). The Development Of Educational Puzzle Game Based On The Local Wisdom Using Flash Media To Educate The Students'characteristic of Primary School. Refleksi Edukatika: Jurnal Ilmiah Kependidikan, 9(2). 